Alina COJOCARU

Faculty of Letters, Ovidius University

Constanța, Romania

alina.cojocaru@univ-ovidius.ro

\title{
DISLOCATED IDENTITIES, ERASED MEMORIES: THE DYSTOPIAN ARCHITECTURE OF INNER SPACES IN J.G. BALLARD'S HIGH-RISE
}

Recommended Citation: Cojocaru, Alina. "Dislocated Identities, Erased Memories: The Dystopian Architecture of Inner Spaces in J. G. Ballard's High-Rise”. Metacritic Journal for Comparative Studies and Theory 6.1 (2020): https://doi.org/10.24193/mjcst.2020.9.05

\begin{abstract}
What would a dystopian version of London look like? How would the architecture of the near future engage with personal and collective memories in order to define, or even transform the identities of the inhabitants? In an attempt to answer these questions, British New Wave science fiction turns its attention to the exploration of urban dwellers in relation to their dystopian surroundings. This article explores the extent to which the novel High-Rise by J.G Ballard highlights the erasure of memories and ultimate mayhem caused by the architectural design, as well as the interplay between identity and architectural identity. I conduct a geocritical analysis, emphasizing the connections between the animate inhabitants and the inanimate building as the main guiding force of the plot. I focus on the importance of both architecture and memory in creating dystopian, alienating urban surroundings which transform and are transformed by the self to the extent that they are both marked by an entropic conception of the future.
\end{abstract}

Keywords: geocriticism, inner space, entropy, memory, identity.

\section{Introduction: inner space identities}

The fiction of J. G. Ballard delves deep into the human psyche, not only by exploring the relationships between its characters, but also by conveying the cityscape in terms of the mind. Either real or imaginary, the urban spaces reflect and are reflected by 
the minds of the protagonists. Influenced by the psychoanalytic theory of Sigmund Freud, the Jungian model of the psyche, the experiments in anti-psychiatry initiated by R.D. Laing, as well as the technological advancements of the new millennium, Ballard proposes a new type of fiction. The aim of his pursuit is to answer some of the pressing issues that the self is confronted with in an urban milieu which is gradually becoming more dehumanized and impersonal.

At the turn of the new millennium a distinct group of British writers repudiated the conventional themes and settings of science fiction and advocated instead for a break with tradition in the form of a more grounded type of narrative, in terms of the subject matter, yet radical and subversive in terms of style. In this respect, Ballard has come to be regarded as "a literary maverick, an imaginative radical, a transgressive, subversive writer unafraid to violate taboos and to voice unspoken truths about the state of modern humanity" (Francis 7). New Wave science fiction morphed the genre in order to accommodate an augmented experimental dimension akin to the avant-garde writings of Jorge Luis Borges and William S. Burroughs (Merrick 103), in opposition to its stereotypical interstellar, scientific, pulp features which cast over science fiction a disreputable image. The magazine New Worlds offered Ballard and other British and American writers such as Michael Moorcock or Thomas Pynchon the freedom to explore the new dynamics between the human and the artificial, the cityscape and the mindscape, the inner and outer, real and imagined spaces engendered by a world of cybernetic prosthesis. His endeavour materialized not only in a distinction of Commander of the Order of the British Empire, which Ballard declined, but also in the acknowledgement of science fiction as a genre worth attaining literary recognition.

The concept of inner space emerged as a requisite concept in portraying the spatial experiences of the self when faced with an uncanny environment on the brink of collapse. Coined by Ballard in the essay "Which Way to Inner Space?", which was subsequently included in the collection A User's Guide to the Millennium: Essays and Reviews, Ballard affirms that "[t]he biggest developments of the immediate future will take place not on the Moon or Mars, but on Earth, and it is inner space, not outer, that needs to be explored. The only truly alien planet is Earth" (Ballard 1996,197). In doing so, repressed memories are brought to the surface and the readers, together with the protagonists, are persuaded to re-evaluate the world they inhabit, perhaps even turn their gaze inwards instead of being entranced by the 
ubiquitous technological advancements. As Freud remarks, repression "[1]ies simply in the function of rejecting and keeping something out of consciousness" (147). Arguably, for the protagonists of High-Rise, this inhibitory control occurs willingly and architecture plays a vital role in erasing the past. This being said, inner space is for Ballard the "fusion of the outer world of reality and the inner world of the psyche" (Ballard 1996, 84). Accordingly, the contrived environment of the high-rise and its surroundings are touched by calamities and fragmented to the extent that the task of the characters is to create meaning from these fragments and re-establish a connection between the inner and the outer spaces. Therefore, space becomes a liminal instance, bridging the internal and the external into a cycle of action and reflection.

Due to the antipodal nature of apocalyptic narratives in relation to a zeitgeist of searching for meaning, one of the omens which foreshadow the dystopian turn to the ambitious architectural project depicted in High-Rise is the rejection of any traces of personal or collective memory. The architecture of the high-rise which resembles a vertical city bears no indication of any temporal or historical determinacy. According to Gomel, "Ballard forces his readers to consider not what might happen after the end, but rather their own desire for time to end" (189) or, as Derrida states, to contemplate "the disorder or delirium of destination" (24). The desire to erase painful personal memories or the feeble collective memories of the nation manifests into the dismissive attitude towards both past and future. Carl Jung talks about a collective unconscious, stating that "[t]here exists a second psychic system of a collective, universal, and impersonal nature which is identical in all individuals" (Jung 43). Interestingly enough, the appeal of an undivided self, made up of "pre-existent forms, the archetypes, which can only become conscious secondarily and which give definite form to certain psychic contents" (Jung 43) may allude to the architectural structure of the high-rise which is an enclosed system. In the same vein, Maurice Halbwachs used the term "collective memory" to argue that identity can only be formed collectively. Thus, the politics of memory may very well stand at the centre of the dystopian architecture which initially mirrors a collective nostalgia for unity when facing a changing environment.

Nevertheless, as Jean-Luc Nancy points in his study, The Inoperative Community, the idea of an idealized, small community which could save its inhabitants from alienation is not and has never been feasible. For him, "[f]initude, 
or the infinite lack of infinite identity, if we can risk such a formulation, is what makes community" (Nancy xxxviii). Therefore, the shaping and affirmation of the unique features of one's identity seem to be smothered, not encouraged by the community which induces uniformization and imposes limits. Arguably, the finitude and limits that Nancy mentions are made visible in High-Rise through the imagery of the levels and elevators as spatial metaphors for the stratification and constraints of community. Consequently, for Nancy the ever-present nostalgia regarding a community which would restore the ties between individuals and counter their selfishness represents an illusion which he considers rather totalitarian (Nancy 1415). As opposed to the collective existence conjured by Jung or Halbwachs, Nancy is rather inclined to think that, at its core, society cannot mobilize and work towards a common goal since there are no strong memory ties to talk about. In consequence, a functioning clockwork society closed upon itself may be seen as a mere myth.

In addition to the relations between the architecture of the inner space, identity, and memory, another connection has been made by J.G. Ballard in an interview to "the invented space that you see in dreams and surrealist paintings in particular, but also in highly dislocated realities such as war zones, sites of plane crashes, earthquake aftermaths, derelict buildings, where the observer imposes his own dreams, fears, phobias" (in Francis 67). In other words, inner spaces may mirror both the physical collapse of external space and the dissolution of the individual. It is worth noting that the name of the most prominently featured character in the novel High-Rise takes the name and profession of the real-life Scottish psychiatrist R.D. Laing, a promoter of anti-psychiatry. The weaving of the mind and the high-rise reveals an "ongoing interest not just in the relationship between the real and the imaginary but also in the dialectics of deviance and normalcy" (Delville 19). In light of the aforementioned dimensions, which may be attributed to the concept of inner space, it is a requisite to discuss the dystopian high-rise featured in the novel as a fusion of the physical and the psychological reflected in various mental spatial transformations.

\section{From Brutalism to brutality: identity enclosed by architectural identity}

The portrayal of the high-rise foreshadows depersonalization, defamiliarization and ultimately dehumanization. The descent of the protagonists into acts of unspeakable violence is made known from the very first lines of the novel: "Later, as he sat on his 
balcony eating the dog, Dr Robert Laing reflected on the unusual events that had taken place within this huge apartment building during the previous three months" (High-Rise 13).In this respect, the novel may very well be regarded as a diagnosis of the chain of events which has led to the coming into being of the new housing project and the impact of the agglomeration of a cohort of individuals in an increasingly cramped environment. The notion that "the high-rise was a model of the world into which the future was carrying them" (High-Rise 176) alludes to the inevitability of the collapse.

With that in mind, New Wave science fiction emphasizes yet another principle which dispels the idea of a linear social evolution towards a harmonious personal and group identity and opts instead for the vision of a rise, peak and fall of any physical or psychological structures, only to renew the same path of evolution in a loop. The principle described is that of entropy. Ballard borrows the principle from the Second Law of Thermodynamics and applies it to his writing in order to convey a rather fatalistic vision of existence. As Deville clarifies, entropy represents "a hypothetical tendency of the universe to attain a state of maximum homogeneity in which all matter is at a uniform temperature and eventually brings about the 'heat death' of the universe" (18). The metamorphosis of the high-rise from the pinnacle of human ingenuity to proof of the debasement of morality in times of material prosperity is in tune with the scientific observations. In spite of the apparent affluence of the inhabitants, the need to rise to the upper echelon produces social unrest and loss of the values which constitute the core of personal identity. As soon as the building starts to deteriorate, the minds of the dwellers are in tune with the changing environment.

What Ballard accomplishes with High-Rise is to foreshadow one of the greatest changes brought to the London cityscape as a result of urban overcrowding and overseas investments, namely the skyscraper boom. The predicament of a society turned upside down as a result of class struggle, to the point that it retrogresses into primitivism, albeit an exaggeration, turns the attention of the reader to the cardinal importance of spatiality and urban planning to the development of the city and the well-being of its citizens. J.G. Ballard was perhaps able to foresee the more complex implications of erecting vertical microcosms completely disconnected from the personal and collective history: 
In principle, the mutiny of these well-to-do professional people against the building they had collectively purchased was no different from the dozens of well-documented revolts by working-class tenants against municipal tower-blocks that had taken place at frequent intervals during the post-war years. (High-Rise 87)

Westphal observes in Geocriticism: Real and Fictional Spaces that "fiction detects possibilities buried in the folds of the real" (Westphal 103). Reading High-Rise, it would seem that the crises of the world we live in are encoded in the materiality which surrounds us. The spatial logic resonates with the technological complexity and the ever-increasing egotism which create the image of a society where the most prominent stimuli are those of a visual nature. Crosthwaite envisages the protagonists of Ballard's novels as "hollowed out", "consumed by their own representations" and consumers of "an ever-expanding media realm" engendering "derealizing effects" (Crosthwaite 20-22). Stephenson goes even further and points out the "reduction of human individuals to objects" (64), indicating the lack of affect, the altered sense of humanity inherent in the interactions mediated by technology. The centrality of tower blocks in modern day existence incites a new dialectics of inner and outer spaces. In High-Rise, it seems as if the limited perimeter of the apartments and hallways is all that the inhabitants have ever known and are ever capable of knowing. They all willingly surrender themselves to a life of self-imposed isolation, content that their base needs are going to be satiated. Any interest for the outside world disappears in their microcosm. The novel creates a simulated space which exacerbates the artificial landscape of the late twentieth century and brings it closer to the mental processes.

When examining the real and imagined spaces of High-Rise, it should be pointed out that the exact setting of the novel in terms of toponymy and time frame is not made clear in the novel, hence giving the events a universal character. Nevertheless, examining the transformations that London was undergoing around the time the novel was written, it is reasonable to assume that the one of the incentives to choosing the gargantuan building as the setting was the prospect of a boom in building projects to restore the commercial landmarks which had been destroyed during the Blitz. Applying geocritical theory to the novel highlights the commentary against the mass urban proliferation of impersonal, prefabricated constructions made of concrete blocks and glass. Accordingly, it is not the west, but 
the east side of London which becomes a privileged ground for the examination of the palimpsest nature of the capital. The area of the London Docklands is brought to attention:

Laing was still exhilarated by the high-rise, one of five identical units in the development project and the first to be completed and occupied. Together they were set in a mile-square area of abandoned dockland and warehousing along the north bank of the river. The five high rises stood on the eastern perimeter of the project, looking out across an ornamental lake-at present an empty concrete basin surrounded by parking lots and construction equipment. (High-Rise 7)

Thus, the novel may have anticipated the postwar capitalism proposed by Margaret Thatcher which marked the step into a new age of privatisation and consumerism. Westphal refers to "homotopic consensus" when the fictional space can be recognized in real life and reveals the potentials of an area to such an extent that the boundaries between them are blurred (102-110). The high-rises cover a wide area of abandoned buildings along the river, reminiscent of the skyscrapers erected in Canary Wharf in the 1970s with the aim of revitalising the area of London Docklands and boosting the economy. The visionary aspect of the novel lies in its ability to use inner spaces to harness the past and the present in which it was written in order to anticipate the future. Ballard creates "a landscape beyond technology where everything was either derelict or, more ambiguously, recombined in unexpected but more meaningful ways" (High-Rise 176). The cohesion of community and the foundations of identity are tested to an unprecedented scale, which is both familiar and alien.

That being said, the dystopian architecture conjured in the novel pertains to Brutalism, an architectural style which has its origins in the mid twentieth century but fits the requirements of a fast-growing population marked by depersonalization. The postwar state encouraged the construction of affordable housing which required low-cost materials and answered the need for efficiency and control over the environment. A vast number of buildings were materialized in a short amount of time hence the architectural style chosen had to be equally austere. In Towards a New Architecture, Le Corbusier traced the architectural ethos which would gain massive popularity twenty years later and continue to evolve until present days. For Le Corbusier, "[t]he great problems of modern construction must have a geometrical solution" (qtd. in Kruft 398). The solution for overcrowding is to aspire towards 
offering not a home to the citizen, but "a machine for living in" (qtd. in Kruft 398). Initially referred to as unités d'habitation, characterized by standardized, cheap, resilient surfaces made out of concrete and glass, these places were designed to create a sense of unity and togetherness by means of architecture. In London, Ernö Goldfinger was the one to take advantage of the remaining rubbles of the buildings displaced after the Blitz and create several high-rise buildings. One of them, and perhaps the most famous, was Balfron Tower in East London, whose rigid lines of the exterior were in tune with the cold, pristine surfaces of the interior and may have influenced the portrayal offered by Ballard in the novel.

Brutalism changed the face of London and marked a new worldview. According to critics, "[t]he proliferation of dystopian urban visions in the early $1970 \mathrm{~s}$ reflected a growing awareness of the environmental costs of urbanism" and the focus on this particular architectural typology was due to "the perceived failure of what were then predominately buildings for social housing" (Dobraszczyk 116). Dobraszczyk then mentions a number of high-rises across Britain which deteriorated soon after their completion, from Ronan Point to Hulme Crescents. In the novel, the construction paradoxically collapses despite being a private luxurious tower block, proof that the centre that cannot hold is not necessarily a result of poor infrastructure. After all, Anthony Royal is portrayed as an accomplished architect. Instead, the deterioration of the structure comes from within. The inhabitants are the ones who willingly succumb to the urge to wreck the seemingly flawless design of the high-rise carefully planned by the man who lives on the top floor of the skyscraper.

Three years before the publication of High-Rise, Oscar Newman's study Defensible Space: People and Design in the Violent City (1972) explored the American city and reached the conclusion that urban planning can foster violence and that tower blocks, in particular, encouraged antisocial behaviour. Later, in his design guidelines for creating such defensible spaces, he encourages "the reassignment of physical areas and areas of responsibility - the demarcation of new spheres of influence" (Newman 3). As for Ballard's imagined high-rise, it is clear that the transition from one space to another, albeit private, can be easily done, with the inhabitants even leaving their doors wide open to anyone who should wish to attend their parties. People are left to their own devices, perhaps due to the architect's traditional belief in an identity which is grounded in the Jungian collective unconscious, yet the outcome of doing so follows the predictions outlined by 
Newman. In this respect, Ballard chooses to populate the building only with damaged, corrupt individuals, a fact which may raise a few eyebrows but the hyperbolic scale of the mayhem alludes precisely to the fragility of any man-made construct.

In an interview, Ballard confesses that he did do research before embarking on the journey of writing this novel and discovered that "in cities the degree of criminality is affected by liberty of movement: it's higher in cul-de-sacs. And highrises are culs-de-sac: two thousand people jammed together in the air" (Ballard qtd. in Bell). The high-rise lacks the natural surveillance system of the spaces which are inside and outside the building, hence the design which is supposed to bring people closer together ironically spurs urban violence. Doctor Robert Laing, the protagonist of the novel, openly expresses that his moving into the high-rise is precipitated by a difficult divorce which left him feeling despondent and vulnerable. He perceives the change of environment as a sort of self-isolation in the midst of times marked by disillusionment. He locks himself in "a huge machine designed to serve, not the collective body of tenants, but the individual resident in isolation" (High-Rise 17). Anthony Royal refers to the apartments in the high-rise as "gigantic vertical zoo, its hundreds of cages stacked above each other" (High-Rise 134). Social disconnection may be interpreted as a symptom of the dystopian architecture or the design of the high-rise may be influencing the behaviour of the masses. In this respect, the highrise embodies the disengagement with the past and from the self together with its nefarious effects. The movement within the building causes a sort of topophobia (Trigg) and paradoxically the act of ascending the levels of the tower block leads to anxiety and unleashes a primitive behaviour engendered by class struggle, as well as the desire for material possessions. Conversely, the literal descent outside the highrise and metaphorical descent into the recesses of the mind brings comfort.

\section{Dystopian architecture and the dissolution of the self: "an environment built, not for man, but for man's absence"}

The high-rise offers the promise of a new beginning, a blank slate on which the dwellers can write their own memories and refashion their selves. In the context of the inner spaces conjured by Ballard, the imagery of space as an impersonal instance harkens to the Lockean conception of the mind as tabula rasa. The building is turned into "an environment built, not for man, but for man's absence" (High-Rise 
25). However, once all traces of memories have been erased and the past has been repressed, the principle of entropy comes into action. Consequently, once the palimpsest of memories is obliterated neither the urban fabric nor the mind can function properly. As Neumann states, "individuals and groups remember their past and (...) construct identities on the basis of the recollected memories" (Neumann 333). The transformations in the urban milieu paired with the dislocated identities of the protagonists who are thrown into an unfamiliar environment generate conflicts and dissolutions.

Furthermore, the impact of the inhabited space on the mind and vice versa suggests that identity is forged by the technologies and objects that surround the protagonists. After the descent into primitivism and the shattering of the once luxurious interior, Laing observes the pieces of furniture, only to realize that he "found it hard to remember what their original function had been. To some extent they had taken on a new significance, a role that he had yet to understand." (HighRise 146-7) The shapes and angles of the high-rise, "the cluster of auditorium roofs, curving roadway embankments and rectilinear curtain-walling” (High-Rise 34), do not point to anything remotely human but create instead "an intriguing medley of geometries-less a habitable architecture, (...) the unconscious diagram of a mysterious psychic event" (High-Rise 34). Eventually, the collapse confirms that any space devoid of memories cannot function as a self-regulatory system. The rejection of any ties to the past does not eliminate the traumas of a troubled past. On the contrary, the repressed makes its appearance in a violent fashion.

The connection between the individual and home is explored by Gaston Bachelard who points out in The Poetics of Space that a man without a home is a "dispersed being" to the extent that interior space becomes the "body and soul" or "the human being's first world" (7). In other words, for Bachelard the objects which surround us in our daily lives have the role of offering psychological stability and sustaining humanity. Space and being become interchangeable, both in a state of symbiosis, with the former grounding the perception of the latter about the external world. Therefore, the destruction of the infrastructure of the high-rise as a sign of receding into a primitive state makes sense, inasmuch as the farrago of debris and ruins is symptomatic of and a symptom of self-annihilation or, better still, annihilation of the self. In the circumstances of living in the high-rise, one can no longer talk about the notion of "dwelling". The psychological comfort offered by a 
sense of place is replaced by "infinite space that is everywhere homogeneous and nowhere distinctive" (Heidegger 249). There is no form of spiritual unity between the residents and the material world. The interiors, albeit luxurious, do not receive a deeper meaning, so the state of dwelling, the essence of existence which gives us humanity according to Heidegger, is beyond the reach of the protagonists.

Anthony Royal, Robert Laing and Richard Wilder play, according to critics, "the roles of the Freudian superego, ego and id of the high-rise itself" (O'Hara 106) from which it can be derived that the building itself is anthropomorphized. The tower block has a "huge animate presence, brooding over them and keeping a magisterial eye on the events taking place" with "the elevators pumping up and down the long shafts" which "resembled pistons in the chambers of a heart" (High-Rise40). Indeed, the design of the high-rise informs the psyche of the inhabitants. The inhabitants are likened to "cells in a network of arteries" and "the lights in their apartments" resemble "the neurones of a brain" (High-Rise 51). The descent into primitivism coincides with the power shortages, malfunctioning lifts, brawls between neighbours, the gathering of piles of garbage in the hallways and the overall lack of sanitation. Machine-like individuals borrow the features of the spaces they inhabit. Lefebvre reinstates the vision of Bachelard that private spaces reflect "the terrible urban reality that the twentieth century has instituted" (Lefebvre 120-1). In the words of Richard Wilder's wife, Helen, "there's too much hostility (. . .) it's always been there, but now it stands out (. . .) it's not really the other residents, it's the building" (HighRise 46). Arguably, the protagonists have no spatial landmarks that could instil in them a sense of togetherness, hence no moral compass to guide them.

The concrete, steel and glass inhibit the formation of a sense of belonging, important for cultivating a sense of belonging to a community. As a countermeasure, David Harvey draws attention to the importance of places of memory such as monuments, shrines, museums in the creation of a rooted community, noticing that "[t]he effort to evoke a sense of place and of the past is now often deliberate and conscious" (Harvey 302). Whether rootedness in community is a utopia (Nancy), a natural fact which facilitates "dwelling" or a spiritual unity with the material (Heidegger), a psychological given (Jung) or an imaginary construct (Harvey), the relation between space, memory and identity is highlighted in all cases.

In the case of High-Rise, the private and the public are interchangeable while the past, present and future merge into an ever-lasting present which confuses the 
inhabitant: "[t]he internal time of the high-rise, like an artificial climate, operated to its own rhythms, generated by a combination of alcohol and insomnia" (HighRise12). Emil Cioran talked about utopias as "a counterfeit of eternal present" (104). The eternal present takes a dystopic, apocalyptic turn but entices at the same time a self-conscious exploration after actions take an extreme dimension, according to the principle of entropy. As Harvey states, "[t]he preservation or construction of a sense of place is then an active moment in the passage from memory to hope, from past to future" (306). Devoid of a sense of place and dazed by the unnatural rhythms caused by excesses, the unrooted self gets lost in the indefinite spatial and temporal coordinates.

Ballard proposes a vision of the built environment which accommodates this return of the repressed inasmuch as it explores the ways of being human to the brink of crisis. The outcome of the experiment suggests that the effective design of space matters. In fact, the novel very much emulates the actual experiment conducted by John B. Calhoun in 1947. Fascinated by the relation between human behaviour and spatiality, Calhoun designed a utopia for rats. The colony of rats was provided with everything they needed to appease their hunger, quench their thirst and take shelter. Space was the only commodity that would not bend to the needs of the rapidly growing population. When faced with crowding, the rats exhibited a pathological behaviour, from gang violence to negligent parenting. Naturally, "Calhoun's experimental designs reflected his concern with human populations: his rodent homes resembling high-rise tower-blocks complete with narrow stairwells and congested entrances." (Ramsden and Adams 766). Consequently, the macabre spectacle of the mice, which came to be regarded as scientific evidence, was turned into evidence of an impending social decay.

Paying attention to the meticulously designed apartments of his neighbours, Laing is "physically repelled" (High-Rise 100) by the good taste and intelligence displayed by Royal when transforming the space into a perfect combination of functionality and design. Arguably, the impeccable taste which is present in every room robs the dwellers of their individuality. No object from outside the enclosed environment is in sight, no detail which does not match the bigger picture stands out. Even though the high-rise is not conceived as a prison, but as an earthly paradise, one cannot help but notice the "great carceral continuum" (Foucault 289) in the imagery of control and omnipresence of the figure of the architect materialized in the 
fastidious choice of interior design elements. Still, Royal is relieved when uniformity is broken:

In a sense, these people were the vanguard of a well-to-do and well-educated proletariat of the future, boxed up in these expensive apartments with their elegant furniture and intelligent sensibilities, and no possibility of escape. Royal would have given anything for one vulgar mantelpiece ornament, one less than snow-white lavatory bowl, one hint of hope. Thank God that they were at last breaking out of this fur-lined prison. (High-Rise 100)

When addressing the issue of social class, gentrification and space, Edward Soja proposes the term "spatial justice". The terminus ad quem of his study Seeking Spatial Justice is "to stimulate new ways of thinking about and acting to change the unjust geographies in which we live" (5). In consonance with Calhoun's experiment, the struggle for space transforms the initial disputes and antagonisms into an actual war. Certain parts of the building are claimed by several newly formed gangs who position "metal railing and water pipes crisscrossed the shafts, inserted like stop indicators" (High-Rise 52). Laing is forced to barricade himself inside the apartment and block every entrance lest some intruders come to claim his space and take his life. Once the elevators break, parts of apartments are used as means of getting from one floor to the other. Pieces of furniture are used as weapons and the already liminal character of the high-rise, situated between the public and the private, acquires a new function, that of a theatre of war operations.

The virulent reactions to the environment manifest themselves not only visually, but also aurally. For Rodaway, "the senses are geographical in that they contribute to orientation in space, an awareness of spatial relationships and appreciation of the specific qualities of different places, both currently removed and experienced in time" (37). The curiosity of the newcomers about the noises which can be heard coming from above them reveals that the reason for celebration is the occupation of all apartments, hence reaching full capacity. Ironically, if Calhoun's study is to be taken seriously, what they are all celebrating is actually their future demise. On the first day following overcrowding, a carnivalesque atmosphere takes hold of the inhabitants and the passage of days and nights is replaced by a constant celebration. Laing calls it "an impromptu amateur circus" (High-Rise 38). Decadence is conveyed aurally, with parents neglecting their children or encouraging them to 
drink, people shouting, dancing, singing or being outraged not because of the abnormal behaviour but because their expensive possessions are being damaged (High-Rise 38). The shift in the power balance is thus foreshadowed.

Given that the high-rise has levels, the interpersonal connections are limited. Only through sounds can the inhabitants of each level assume what is happening around them. Still, they tune in to the soundscape. Faced with a world turned upside down, even Laing cannot do anything but join in the singing, laughing and joining "the wild surge across the elevator lobby" (High-Rise 42). As the three-month stay in the high-rise progresses, the verbal interactions between individuals decrease and, instead, sounds distinguish themselves as the main uniting element, first as signals that the euphoric and epicurean attitude towards existence still has a hold on the dwellers and later in the form of "tremors, sinister trickles of sound" (High-Rise 175) which indicate that a potential threat is approaching. Sounds intensify gradually until the critical point of entropy is reached. The alignment of the belligerent dynamics with modern urban development places the catastrophic and the mundane on an equal footing. As soon as the last level of the high-rise has been taken over and depleted, silence suggests the return to a new beginning.

\section{Conclusion}

Remapping the city by means of high-rises represents a reality which is inadvertently acknowledged but rarely questioned. Urban spaces do not represent mere empty vessels, but repositories of personal and collective memories. In J.G. Ballard's HighRise, the tower block acquires a dystopian dimension once the protagonists are removed from their respective milieu, which is imbued with traces of the past, and placed in the blank slate of concrete, glass and steel. The aforementioned studies on the relation between space, memory and identity, which range from geocriticism to social history and philosophy, suggest that the impersonal character of the building translates into the attempt of achieving a new urban identity. Nevertheless, the goal of reverting to a state of tabula rasa is proven implausible. In line with the principle of entropy, events are slowly unfolding towards sameness and equilibrium, only to spontaneously combust. Visual and sensory stimulation ultimately contributes to the fashioning of a self-indulgent cycle of destruction and creation. The novel demonstrates that identity may be interpreted as a construct which can have an 
internal logic as long as it unravels against a spatial and temporal context, akin to a narrative. Once these instances disappear, identity itself becomes illegible.

\section{References:}

Bachelard, Gaston. The Poetics of Space. Tr. Maria Jolas. Beacon Press, 1994.

Ballard, J.G. High-Rise. Norton, 2012.

---. "Which Way to Inner Space?”. A User's Guide to the Millennium: Essays and Reviews. Picador, 1996: 195-8.

Bell, Duncan. "Scripting the City: J. G. Ballard Among the Architects." Political Theory and Architecture, edited by Duncan Bell and Bernardo Zacka, Kindle edition, Bloomsbury Publishing, 2020.

Cioran, E.M. History and Utopia. Tr. Richard Howard. Seaver Books, 1987.

Crosthwaite, Paul. Trauma, Postmodernism, and the Aftermath of World War II. Palgrave Macmillan, 2009.

Derrida, Jacques. "Of an Apocalyptic Tone Recently Adopted in Philosophy." Tr. John P. Leavey, Jr., Oxford Literary Review, vol.6/2, 1984: 3-37.

Delville, Michael. J.G. Ballard. Northcote House, 1998.

Dobraszczyk, Paul. Future Cities: Architecture and the Imagination. Reaktion Books, 2019.

Foucault, Michel. Discipline and Punish: The Birth of the Prison. Tr. A. Sheridan. Penguin Books, 1977.

Francis, Samuel. The Psychological Fictions of J. G. Ballard. Continuum, 2011.

Freud, Sigmund, and Joan Riviere. A General Introduction to Psychoanalysis. Liveright, 1963.

Gomel, Elana. "Everyday Apocalypse: J G Ballard and the Ethics and Aesthetics of the End of Time." Partial Answers: Journal of Literature and the History of Ideas, vol. 8.1, 2010: 185-208.

Halbwachs, Maurice. The Collective Memory. Tr. F.J. Ditter, Jr. and V.Y. Ditter. Harper \& Row, 1980.

Heidegger, Martin. Poetry Language Thought. Harper \& Row, 1971.

Harvey, David. Justice, Nature, and the Geography of Difference. Blackwell, 1996.

Jung, Carl Gustav. The Archetypes and the Collective Unconscious. Princeton University Press, 1996. 
Kruft, Hanno-Walter. History of Architectural Theory. Princeton Architectural Press,1994.

Lefebvre, Henri. The Production of Space. Tr. Donald Nicholson-Smith. Blackwell, 1991.

Merrick, Helen. "Fiction, 1964-1979." The Routledge Companion to Science Fiction, edited by Mark Bould, Andrew M. Butler, Adam Roberts, and Sherryl Vint, Routledge, 2009: 102-11.

Nancy, Jean-Luc. The Inoperative Community.Tr. Peter Connor et al. University of Minnesota Press, 1991.

Neumann, Birgit. "The Literary Representation of Memory." Cultural Memory Studies: An International and Interdisciplinary Handbook, edited by Astrid Erll and Ansgar Nünning, Walter de Gruyter, 2008: 333-45.

Newman, Oscar. Creating Defensible Space. Center for Urban Policy Research, Reutgers University (U.S. Department of Housing and Urban Development Office of Policy and Research), 1996.

O’Hara, Dan. "Reading Posture and Gesture in Ballard's Novels.” G. Ballard: Visions and Revisions, edited by Jeanette Baxter and Rowland Wymer, Palgrave, 2012: 105-22.

Ramsden, Edmund and Adams, Jon. "Escaping the laboratory: the rodent experiment of John B. Calhoun and their cultural influence.” Journal of Social History, vol. 42 (3), 2009: 761-797.

Rodaway Paul. Sensuous Geographies: Body, Sense, and Place. Routledge, 1994.

Soja, Edward. Seeking Spatial Justice. University of Minnesota Press, 2010.

Stephenson, G. Out of the Night and into the Dream: A Thematic Study of the Fiction of J.G. Ballard. Greenwood, 1991.

Trigg, Dylan. Topophobia: A Phenomenology of Anxiety. Bloomsbury, 2017.

Westphal, Bertrand. Geocriticism: Real and Fictional Spaces. Palgrave Macmillan, 2011. 